\title{
Impact of the burrow-dwelling polychaete Nereis diversicolor on the degradation of fresh and aged macroalgal detritus in a coastal marine sediment
}

\author{
Erik Kristensen*, Ole Ladefoged Mikkelsen
}

Institute of Biology, University of Southern Denmark, 5230 Odense M, Denmark

\begin{abstract}
Impacts of the irrigating and detritus-feeding polychaete Nereis diversicolor on degradation of fresh and aged ${ }^{14} \mathrm{C}$ labeled Fucus serratus detritus deposited into sandy marine sediment were examined in microcosm experiments. The fate of detritus deposited at the surface or buried $3 \mathrm{~cm}$ into the sediment was followed over a period of $18 \mathrm{~d}$. Fluxes of solutes (total labeled $\mathrm{CO}_{2}$ $\left[\mathrm{T}^{14} \mathrm{CO}_{2}\right]$ and labeled dissolved organic carbon $\left.\left[\mathrm{DO}^{14} \mathrm{C}\right]\right)$ across the sediment-water interface in the absence and presence of $N$. diversicolor were compared to changes in pool size and distribution of these solutes and labeled particulate carbon $\left(\mathrm{PO}^{14} \mathrm{C}\right)$ within the sediment. The results showed that fresh detritus at the surface of defaunated sediment was degraded twice as fast as aged detritus $\left(\mathrm{k}_{\mathrm{POC}}=18 \times 10^{-3}\right.$ and $8 \times 10^{-3} \mathrm{~d}^{-1}$, respectively, where $\mathrm{k}$ is the decay constant $) . N$. diversicolor increased the surface $\mathrm{PO}^{14} \mathrm{C}$ decay by 35 and $90 \%$ for fresh and aged detritus, respectively. Competition for food between $N$. diversicolor and microorganisms reduced the microbial degradation of fresh detritus at the surface by $20 \%$ compared with defaunated sediment. Enhanced microbial degradability after passage through the gut of $N$. diversicolor was probably responsible for a $20 \%$ increase in microbial decay of surface-deposited aged detritus in faunated compared to defaunated sediment. The decay of subsurface-deposited fresh and aged detritus in defaunated sediment $\left(\mathrm{k}_{\mathrm{POC}}=10 \times 10^{-3}\right.$ and $3 \times 10^{-3} \mathrm{~d}^{-1}$, respectively) was ca. half of that for surface-deposited detritus. Activities of $N$. diversicolor (irrigation and feeding) increased the degradation of buried $\mathrm{PO}^{14} \mathrm{C}$ by 160 and $270 \%$ for fresh and aged detritus, respectively. The irrigation-associated stimulation of microbial decomposition by injection of oxygen into and removal of toxic metabolites from sediment was 90 and $300 \%$ for fresh and aged detritus, respectively. The several-fold enhancement of microbial decay of aged subsurface detritus substantiates the importance of burrow irrigation and oxygenation for degradation of otherwise refractory detritus in sediments. In the absence of irrigated burrows, a larger fraction of partly degraded detritus may remain undegraded and be buried permanently in the sediments.
\end{abstract}

KEY WORDS: Nereis diversicolor · Irrigation · Feeding · Decomposition $\cdot$ Fucus serratus $\cdot$ Detritus · Oxic/anoxic $\cdot$ Sediment

\section{INTRODUCTION}

Degradation of organic substrates in marine sediments occurs primarily near the sediment-water interface, and is mediated by an array of aerobic and anaerobic microbial processes, as well as detritivorous macrofauna (Lopez \& Levinton 1987, Fenchel et al. 1998). The initial microbial decomposition of newly deposited organic matter occurs at the oxic sediment-water interface, where aerobic bacteria conduct complete degradation of organic carbon to $\mathrm{CO}_{2}$ with oxygen as the electron acceptor. Deposit-feeding animals simultaneously meet their nutritional requirements by ingesting, digesting, assimilating and respiring some of the deposited organic matter and associated microorganisms (Tenore et al. 1982, Lopez \& Levinton 1987). The nutritional value of detritus determines its availability to and utilization by deposit-feeders and microorganisms (Tenore et al. 1984). 
Fresh detritus derived from phytoplankton and macroalgae can directly support detritivore and microbial growth, while aged detritus and detritus derived from vascular plants are less available for microorganisms, and not directly assimilable by most deposit-feeders (Findlay \& Tenore 1982, Kristensen \& Holmer 2001).

A large fraction of deposited organic matter escapes aerobic degradation and is buried into anoxic sediments by passive accretion or mixing by water currents and infaunal reworking (Rusch et al. 2001, Stoeck \& Kröncke 2001). Anaerobic decomposition is accomplished here by mutualistic consortia of bacteria, because no single type is capable of complete carbon oxidation (Fenchel et al. 1998). Hydrolytic and fermenting bacteria first split polymeric organic molecules into smaller and water-soluble organic acids. These are then mineralized completely by respiring bacteria using a variety of oxidized inorganic compounds as electron acceptors (e.g. Fe[III] and $\mathrm{SO}_{4}{ }^{2-}$ ). However, unidirectional redox successions with depth are rare in coastal sediments. Oscillations between oxic and anoxic conditions caused by oxygen leaching from plant roots and irrigated animal burrows result in a temporal and spatial mosaic of microzones, with aerobic metabolism occurring in an otherwise anoxic sediment (Aller 1994, Holmer et al. 2002)

It is well established that benthic macrofauna enhance organic matter degradation in sediments. The magnitude of the faunal impact varies from a few percent in some cases to several hundred percent in many cases, and depends on the specific location, the sediment characteristics and organic matter supply, as well as the functional group, abundance and size of animals present (van Duyl et al. 1992, Banta et al. 1999, Kristensen 2000, 2001, D'Andrea et al. 2002). Burrow-dwelling animals affect microbial processes in 2 major ways: (1) translocation of particles between redox zones during feeding and burrowing activities, and (2) introduction of reactive electron acceptors (i.e. oxygen) into otherwise reduced sediment and removal of reduced metabolites via irrigation (Aller \& Aller 1998, Kristensen 2000). Redox conditions appear to be crucial for the rate of microbial decay as fresh plant detritus is generally degraded equally fast under oxic and anoxic conditions, whereas aged detritus is degraded up to 10 times faster under oxic than anoxic conditions (Hulthe et al. 1998, Kristensen \& Holmer 2001). A number of recent studies have therefore suggested that the oxidation of subsurface sediment via irrigation is more important for microbial degradation than the redistribution of particles by feeding and reworking activities (Banta et al. 1999, Furukawa et al. 2001, D'Andrea et al. 2002). Kristensen \& Holmer (2001), for example, estimated that total sediment carbon oxidation is enhanced up to $80 \%$ by irrigation, but only up to $10 \%$ by particle redistribution.

The faunal impact on microbial processes may not only depend on the type and age of organic matter present in the sediment, but also on interactions between animals and microorganisms. Thus, Kristensen et al. (1992) hypothesized that infaunal irrigation primarily enhances microbial degradation of relatively refractory detritus, while ingestion and metabolization by detritivores diminishes the role of bacteria in the degradation of freshly deposited and labile detritus. The interactions between detritivores and bacteria are probably related to competition for available food sources and animal predation on bacteria through more or less selective ingestion of detritus colonized by microorganisms (Lopez \& Levinton 1987).

We believe that the ideas proposed by Kristensen et al. (1992) and others are important for our understanding of the biogeochemistry and food web dynamics of sedimentary environments. The purpose of this study was therefore to provide experimental verification of the impact of macrofaunal feeding and burrow irrigation on microbial degradation of fresh and aged plant detritus in coastal marine sediment. Our approach was to examine in detail the fate of fresh and predecomposed ${ }^{14} \mathrm{C}$-labeled macroalgal (Fucus serratus) detritus, supplied to either the surface or $3 \mathrm{~cm}$ below the surface of sediment microcosms inhabited by the polychaete Nereis diversicolor over an $18 \mathrm{~d}$ period.

Nereis diversicolor was chosen for the experiments because it has proved to be an ideal model organism in bioturbation studies with a significant impact on sediment processes (Kristensen et al. 1992, Christensen et al. 2000, Kristensen 2001). Its widespread distribution along northern European coasts further substantiates the importance of this polychaete species in coastal areas. $N$. diversicolor lives in 5 to $10 \mathrm{~cm}$ deep U- or Yshaped semi-permanent burrows at densities of up to 4000 ind. $\mathrm{m}^{-2}$ (Davey 1994). It feeds by scavenging all edible items (sediment detritus containing bacteria as well as dead and live animals and plants) around the burrow openings or by filtering suspended phytoplankton by the use of mucus nets (Vedel \& Riisgård 1993, Nielsen et al. 1995). The burrow is frequently reconstructed and actively irrigated by dorso-ventral body movements at rates of up to $4 \mathrm{ml} \mathrm{min}^{-1}$ (equivalent to $10^{3}-10^{4} \mathrm{l} \mathrm{m}^{-2} \mathrm{~d}^{-1}$ at the population level, Christensen et al. 2000).

\section{MATERIALS AND METHODS}

Sediment and worm collection. Sediment and specimens of Nereis diversicolor were collected in November 1998 from the shallow (0.2 to $0.6 \mathrm{~m}$ ) oligotrophic 
marine lagoon, Fællesstrand, at the NE tip of the island of Fyn, Denmark. The lagoon is sheltered from heavy wave action, but the upper few $\mathrm{cm}$ of the sediment are mixed by bioturbation and occasionally by waveinduced resuspension. The sediment is composed of well-sorted, organic-poor sand (17 to $20 \%$ water content, 0.4 to $0.6 \%$ organic content), with a median particle size of $\sim 200 \mu \mathrm{m}$. The macrophyte flora is poor and dominated by patchy growth of Ruppia maritima along the coastline and scattered occurrence of drifting seaweed (Fucus sp.). Benthic microalgae (i.e. diatoms and filamentous cyanobacteria) are the most important primary producers in the lagoon. The benthic macrofauna is dominated by high numbers of $\mathrm{N}$. diversicolor, Corophium volutator, and Hydrobia neglecta. For more details consult Kristensen (1993).

The uppermost 10 to $12 \mathrm{~cm}$ of sediment was dredged and sieved through a $2 \mathrm{~mm}$ mesh on location to remove macrofauna and larger particles. Intact specimens of Nereis diversicolor were collected simultaneously. The freshly sieved sediment was transferred into 24 acrylic core tubes $(5.2 \mathrm{~cm}$ i.d., $30 \mathrm{~cm}$ long) to a depth of $20 \mathrm{~cm}$, allowing a water column of $\sim 10 \mathrm{~cm}$. After return to the laboratory, 3 individuals of $N$. diversicolor $(\sim 400 \mathrm{mg}$ each) were added to each of 12 cores ( $\mathrm{N}$-cores), equivalent to a density of 1400 ind. $\mathrm{m}^{-2}$ and a biomass of $565 \mathrm{~g} \mathrm{~m}^{-2}$ (fresh weight). The worms rapidly dug into the sediment and formed irrigated burrows within $1 \mathrm{~d}$. The remaining 12 cores were used as defaunated controls (D-cores). The cores were subsequently allowed to acclimate for $6 \mathrm{~d}$ at $15^{\circ} \mathrm{C}$ in continuously aerated seawater tanks. Seawater with a salinity of 20 was supplied from the sampling area.

Preparation of ${ }^{14} \mathrm{C}$-labeled Fucus serratus. Actively growing tips of the brown algae $F$. serratus were collected in September 1998 along the pier of Kerteminde Harbor on the east coast of the island of Fyn, Denmark. In the laboratory, the algal tips were placed under continuous light (Grolux, $200 \mu \mathrm{mol} \mathrm{m} \mathrm{m}^{-2} \mathrm{~s}^{-1}$ ) for $7 \mathrm{~d}$ in trays containing $1 \mathrm{l}$ of $18^{\circ} \mathrm{C}$ artificial seawater (salinity of 20) to which was added $\mathrm{H}^{14} \mathrm{CO}_{3}^{-}(1.1 \mathrm{MBq}), \mathrm{NaNO}_{3}$ $(500 \mu \mathrm{M})$, and $\mathrm{KH}_{2} \mathrm{PO}_{4}(50 \mu \mathrm{M})$. Sufficient new tissue was produced during the $7 \mathrm{~d}$ labeling period to ensure that the algal material used in the experiment was homogenously labeled with ${ }^{14} \mathrm{C}$. The average weight gain of 4 portions of $F$. serratus tips was $23 \pm 4 \%$.

After incubation, the algal tips were washed in seawater and minced for $10 \mathrm{~min}$ in a kitchen blender. The material was subsequently sieved through $750 \mu \mathrm{m}$ mesh to remove larger particles and rinsed with seawater in $63 \mu \mathrm{m}$ mesh to remove dissolved carbon compounds. The resulting algal detritus was split into 2 portions. One portion with a molar C:N ratio of 17 and specific activity of $11.0 \mathrm{kBq}$ mmol $\mathrm{C}^{-1}$ was frozen immediately for later use as 'fresh' (F) detritus. The
Table 1. Notation matrix of the 8 different treatments used in the experiment. Fresh (F) and aged (A) detritus were distributed at the surface (surf) or $3 \mathrm{~cm}$ into subsurface (sub) sediment of cores with (N) and without (D) Nereis diversicolor

\begin{tabular}{|lcc|}
\hline & Fresh detritus & Aged detritus \\
\hline Nereis-cores & & \\
Surface & $\mathrm{NF}_{\text {surf }}$ & $\mathrm{NA}_{\text {surf }}$ \\
Subsurface & $\mathrm{NF}_{\text {sub }}$ & $\mathrm{NA}_{\text {sub }}$ \\
Defaunated cores & & \\
Surface & $\mathrm{DF}_{\text {surf }}$ & $\mathrm{DA}_{\text {surf }}$ \\
Subsurface & $\mathrm{DF}_{\text {sub }}$ & $\mathrm{DA}_{\text {sub }}$ \\
\hline
\end{tabular}

other portion was pre-decomposed aerobically in seawater at room temperature for $55 \mathrm{~d}$ to $\sim 60 \%$ of the original radioactivity. After centrifugation, the predecomposed detritus with a molar C:N ratio of 9 and specific activity of $10.6 \mathrm{kBq} \mathrm{mmol} \mathrm{C}^{-1}$ was frozen for later use as 'aged' (A) detritus.

Experimental set-up. To each of $6 \mathrm{~N}$-cores and $6 \mathrm{D}$-cores was added $1 \mathrm{~g}$ wet wt $\mathrm{F}$ detritus $(\sim 23.2 \mathrm{mBq}$ $\mathrm{m}^{-2}$ ), while to each of the remaining $6 \mathrm{~N}$-cores and $6 \mathrm{D}$ cores $1 \mathrm{~g}$ wet wt A detritus was added $\left(\sim 22.8 \mathrm{mBq} \mathrm{m}^{-2}\right)$. The detritus was either spread evenly at the surface of the cores or buried at $3 \mathrm{~cm}$ depth. The subsurface addition was performed by carefully lifting the upper $3 \mathrm{~cm}$ of the sediment core while the detritus was applied. After settling of the detritus and repositioning of the upper $3 \mathrm{~cm}$ sediment, the cores were placed in closed incubation systems. The 3 cores of each of the 8 treatments (Table 1) were, for practical reasons, supplied with recirculating seawater from 1 common reservoir. Thus, each incubation system (Fig. 1) consisted of a

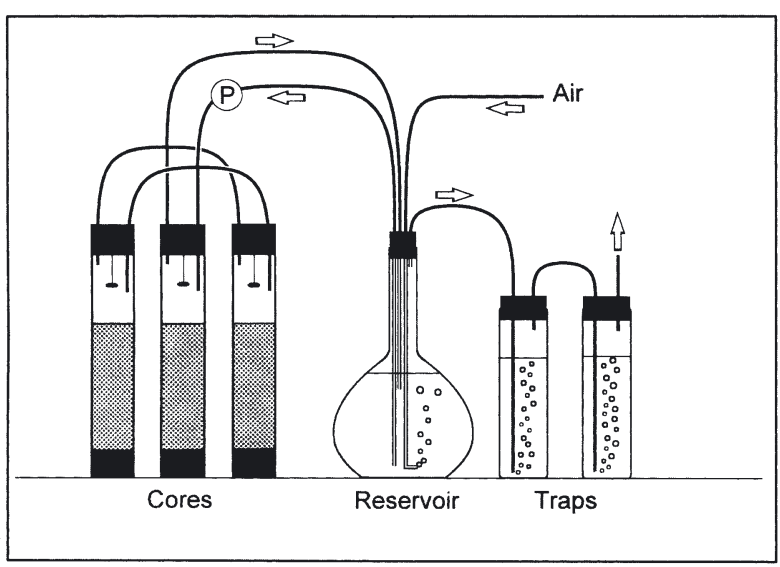

Fig. 1. Schematic presentation of the incubation system. Water flow (arrows) between sediment 'cores' and the seawater 'reservoir' is driven by a peristaltic pump (P). Flow (arrows) of moistened atmospheric 'air' is bubbled through the reservoir and subsequently through $2 \mathrm{NaOH}$ traps 
pump that supplied the overlying water of 3 cores individually (4 $\mathrm{ml} \mathrm{min}^{-1}$ ); a 21 reservoir (renewed every third day), which supplied and received water passing the cores; and $2 \mathrm{NaOH}$ traps (renewed every third day) where the air returning from the reservoir was stripped of all $\mathrm{CO}_{2}$ (including ${ }^{14} \mathrm{CO}_{2}$ ). Each core was supplied with a rotating magnetic bar activated by an externally rotating central magnet (60 rpm) to maintain a homogeneous water phase. All incubation systems were kept in darkness at $15^{\circ} \mathrm{C}$ during the $18 \mathrm{~d}$ experimental period.

Flux measurements. The cumulated release of ${ }^{14} \mathrm{C}$ labeled solutes $\left({ }^{14} \mathrm{CO}_{2}\right.$ and $\left.\mathrm{DO}^{14} \mathrm{C}\right)$ from the sediment in the 3 cores of each system was determined on a $3 \mathrm{~d}$ basis, with samples taken from the reservoirs and traps after every renewal. Samples of $5 \mathrm{ml}$ from the reservoirs were transferred to $25 \mathrm{ml}$ scintillation vials, mixed with $125 \mu \mathrm{l}$ of $1 \mathrm{M} \mathrm{NaOH}$ and $15 \mathrm{ml}$ of scintillation liquid, and counted on a Packard 2200 CA Tricarb scintillation analyzer for determination of total dissolved ${ }^{14} \mathrm{C}$ ( $\mathrm{TD}^{14} \mathrm{C}_{\text {reservoir }}$ ). Other $5 \mathrm{ml}$ reservoir samples were mixed with $250 \mu \mathrm{l}$ of $0.5 \mathrm{M} \mathrm{HCl}$. After purging with $\mathrm{N}_{2}$ for 15 min to remove ${ }^{14} \mathrm{CO}_{2}$, the samples were mixed with $15 \mathrm{ml}$ of scintillation liquid and counted for determination of dissolved organic ${ }^{14} \mathrm{C}\left(\mathrm{DO}^{14} \mathrm{C}_{\text {reservoir }}\right)$. The amount of ${ }^{14} \mathrm{CO}_{2}$ released by aeration of the reservoirs was quantified by determining the radioactivity of $5 \mathrm{ml}$ samples from the $\mathrm{NaOH}$ traps after mixing with $15 \mathrm{ml}$ scintillation liquid $\left({ }^{14} \mathrm{CO}_{2 \text { trap }}\right)$. The total release of ${ }^{14} \mathrm{CO}_{2}$ from the 3 cores in each incubation system was: $\mathrm{T}^{14} \mathrm{CO}_{2}=\mathrm{TD}^{14} \mathrm{C}_{\text {reservoir }}-\mathrm{DO}^{14} \mathrm{C}_{\text {reservoir }}+{ }^{14} \mathrm{CO}_{2 \text { trap }}$.

The exchange of $\mathrm{TCO}_{2}$ across the sediment-water interface of individual cores was determined every third day. The closed-flow system was temporarily disconnected and $25 \mathrm{ml}$ water samples were taken from each of the 24 cores before and after a $4 \mathrm{~h}$ incubation period. $\mathrm{TCO}_{2}$ was analyzed by the flow injection/ diffusion cell technique (Hall \& Aller 1992).

Sediment handling and analysis. The vertical distribution of various carbon pools in the sediment was determined immediately after the final flux incubation. All cores were sectioned into depth intervals of $0-1$, $1-2,2-3,3-4,4-6,6-8$ and $8-10 \mathrm{~cm}$. Worms were collected during sectioning and lyophilized. More than $70 \%$ of the added worms were recovered. Filtered porewater was obtained by centrifuging the sectioned sediment in double centrifuge tubes equipped with $\mathrm{GF} / \mathrm{F}$ filters at $1500 \mathrm{rpm}(375 \times \mathrm{g})$ for $10 \mathrm{~min}$, followed by analysis for $\mathrm{T}^{14} \mathrm{CO}_{2}$ and $\mathrm{DO}^{14} \mathrm{C}$ as described above. The particulate organic carbon content (labeled as well as unlabeled) of dried and ground subsamples of the sectioned sediment and recovered worms, as well as the original fresh and aged Fucus serratus detritus, was analyzed in a Hewlett-Packard 185B CHN analyzer. The ${ }^{14} \mathrm{C}$ content was obtained by trapping the evolved ${ }^{14} \mathrm{CO}_{2}$ from the effluent gas after combustion in the $\mathrm{CHN}$ analyzer, using $2 \mathrm{NaOH}$ traps similar to those mentioned earlier.

Respiration of Nereis diversicolor feeding on ${ }^{14} \mathrm{C}$ labeled detritus. Four average-sized individuals of $N$. diversicolor ( $400 \mathrm{mg}$ ) were transferred to each of 2 cylindrical chambers ( $8 \mathrm{~cm}$ diameter, $15 \mathrm{~cm}$ height). The chambers contained a $1 \mathrm{~cm}$ layer of Fællesstrand sediment mixed homogeneously with $2 \mathrm{~g}$ wet wt of either $\mathrm{F}$ or A detritus. The 2 chambers were maintained for $18 \mathrm{~d}$ in the previously described flow system. The worms were carefully removed from the sediment every third day for determination of $\mathrm{CO}_{2},{ }^{14} \mathrm{CO}_{2}$ and $\mathrm{DO}^{14} \mathrm{C}$ release. Exchange measurements were performed on individual worms in $35 \mathrm{ml}$ stoppered glass bottles containing oxygen-saturated seawater. Worms were gently rinsed in seawater and placed in glass tubes of appropriate sizes (simulating burrows) before transfer to the incubation bottles. Initial and final water samples were taken from the bottles before they were stoppered and immediately after a $\sim 4 \mathrm{~h}$ incubation period, respectively. The bottles were not stirred, but the irrigation activity of worms and gentle shaking of the bottles just before the final sampling assured sufficient mixing of the water. Worms were returned to the chambers immediately after measurements were taken. Water samples were analyzed for dissolved carbon as described above.

\section{RESULTS}

\section{Visual observations}

Nereis diversicolor clearly affected the distribution of detritus added to the sediment surface. Almost all visible detritus disappeared from the surface in $\mathrm{NF}_{\text {surf }}$ and $\mathrm{NA}_{\text {surf }}$ cores within the first $3 \mathrm{~d}$, whereas a distinct layer remained at the surface in $\mathrm{DF}_{\text {surf }}$ and $\mathrm{DA}_{\text {surf }}$ throughout the entire experimental period. All N-cores appeared oxidized with clearly visible irrigated burrow structures to $8-10 \mathrm{~cm}$ depth. The sediment in Dcores, on the other hand, gradually turned black with time due to precipitation of iron sulfides, except for a thin $(<1 \mathrm{~cm})$ oxidized surface layer.

\section{Labeled particulate organic carbon $\left(\mathrm{PO}^{14} \mathrm{C}\right)$}

The vertical distribution of $\mathrm{PO}^{14} \mathrm{C}$ derived from both fresh and aged Fucus serratus detritus showed similar patterns in all parallel treatments (Fig. 2). $\mathrm{PO}^{14} \mathrm{C}$ in the 0 to $1 \mathrm{~cm}$ layer of defaunated sediment with detritus added to the surface accounted for $72\left(\mathrm{DF}_{\text {surf }}\right)$ and $66 \%$ $\left(\mathrm{DA}_{\text {surf }}\right)$ of the total final $\mathrm{PO}^{14} \mathrm{C}$ recovery. The content 


\section{$\mathrm{PO}^{14} \mathrm{C}\left(\mathrm{kBq} \mathrm{cm}^{-3}\right)$}

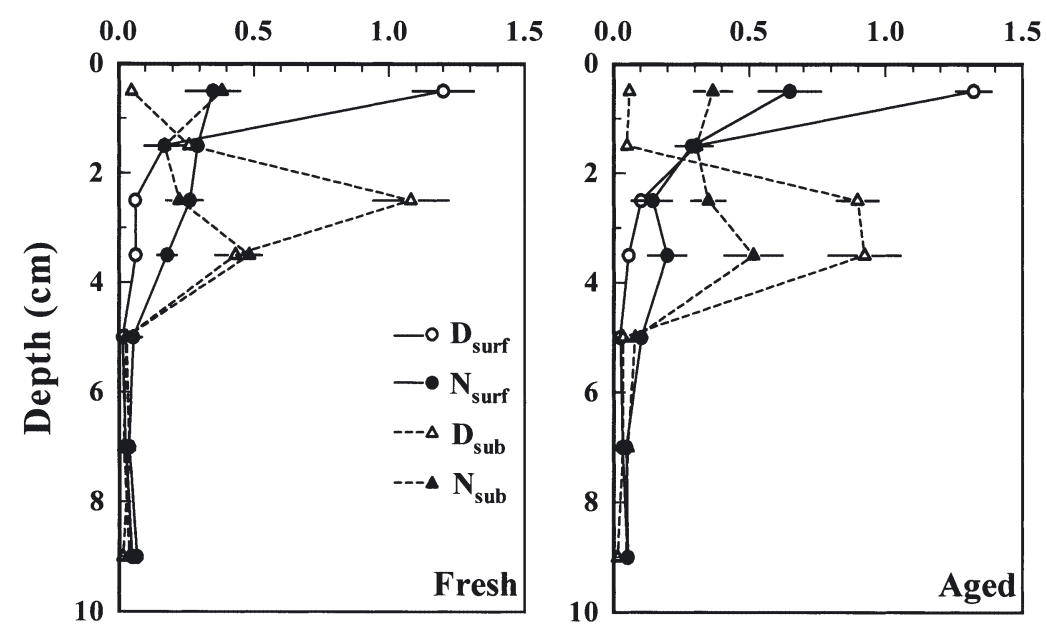

Fig. 2. Vertical distribution of labeled particulate organic carbon $\left(\mathrm{PO}^{14} \mathrm{C}\right)$ in defaunated (D) and Nereis diversicolor (N) sediment with detritus added to the surface $($ surf $)$ and $3 \mathrm{~cm}$ below the surface $($ sub). Treatments with fresh detritus are shown in the left panel and aged detritus in the right panel. Results are given as the mean $\pm \mathrm{SE}$ of results from 3 replicate cores

decreased gradually from 10 and $15 \%$, respectively, at 1 to $2 \mathrm{~cm}$ depth, to $<2 \%$ at 8 to $10 \mathrm{~cm}$ depth. When detritus was added at $3 \mathrm{~cm}$ depth in defaunated sediment, $76 \%\left(\mathrm{DF}_{\text {sub }}\right)$ and $87 \%\left(\mathrm{DA}_{\text {sub }}\right)$ of the total final $\mathrm{PO}^{14} \mathrm{C}$ recovery was obtained from 2 to $4 \mathrm{~cm}$ depth. All other depth intervals only contained between 1 and $3 \%$.

The burrowing activities of Nereis diversicolor smeared the $\mathrm{PO}^{14} \mathrm{C}$ profiles considerably (Fig. 2). Only $25\left(\mathrm{NF}_{\text {surf }}\right)$ and $38 \%\left(\mathrm{NA}_{\text {surf }}\right)$ of the total $\mathrm{PO}^{14} \mathrm{C}$ recovery in sediment with detritus added to the surface was recovered in the 0 to $1 \mathrm{~cm}$ interval. However, each interval down to 3 to $4 \mathrm{~cm}$ depth in these sediments still contained more than $10 \%$ of the total $\mathrm{PO}^{14} \mathrm{C}$ recovery. Subsurface deposited detritus was mixed almost homogeneously into the upper $4 \mathrm{~cm}$ of the sediment. Thus, only $49 \%\left(\mathrm{NF}_{\text {sub }}\right)$ and $46 \%\left(\mathrm{NA}_{\text {sub }}\right)$ of the $\mathrm{PO}^{14} \mathrm{C}$ recovery was found from 2 to $4 \mathrm{~cm}$, whereas 27 and $19 \%$, respectively, was mixed into the 0 to $1 \mathrm{~cm}$ layer.

The depth-integrated loss of $\mathrm{PO}^{14} \mathrm{C}$ was strongly dependent on detritus age and treatment (Table 2). The disappearance of $\mathrm{PO}^{14} \mathrm{C}$ during the experiment is assumed to follow a first-order exponential decay pattern according to: $G_{t}=G_{0} \exp (-\mathrm{k} t)$ (Berner 1980). The first-order decay constant (k) was estimated by selecting the initial $\mathrm{PO}^{14} \mathrm{C}$ content as $G_{0}$ and the final $\mathrm{PO}^{14} \mathrm{C}$ after $t=18 \mathrm{~d}$ as $G_{t}$. The decay of fresh detritus (14 to $39 \%$ loss, $\mathrm{k}=9.9$ to $26.2 \times 10^{-3} \mathrm{~d}^{-1}$ ) was generally 2 to 3 times faster than that of aged detritus ( 6 to $25 \%$ loss, $\mathrm{k}=3.4$ to $15.5 \times 10^{-3} \mathrm{~d}^{-1}$ ) (Fig. 3). Degradation was faster for surfacedeposited than subsurface-deposited detritus in defaunated sediment $(83 \%$ faster for fresh and $144 \%$ faster for aged detritus). However, the impact of detritus positioning was alleviated in the presence of Nereis diversicolor, where the difference of decay rates between surface and subsurface deposition was -7 and $23 \%$ for fresh and aged detritus, respectively. Accordingly, the impact of $N$. diversicolor on degradation was much stronger when detritus was deposited below the sediment surface (165 to $270 \%$ ) than at the surface (35 to $87 \%$ ). Furthermore, the stimulation of decay caused by $N$. diversicolor activities was more pronounced for aged than fresh detritus (i.e. 87 vs $35 \%$ for surface detritus and 270 vs $165 \%$ for subsurface detritus).

\section{Labeled dissolved carbon $\left(\mathrm{DO}^{14} \mathrm{C}\right.$ and $\left.\mathrm{T}^{14} \mathrm{CO}_{2}\right)$ in porewater}

The vertical distribution of dissolved ${ }^{14} \mathrm{C}$ compounds in the sediment was controlled by the position and age

Table 2. Budgets of ${ }^{14} \mathrm{C}$ in microcosms with and without the presence of Nereis diversicolor when fresh and aged Fucus serratus detritus is added to the sediment surface or buried $3 \mathrm{~cm}$ into the sediment. Values are given as mBq $\mathrm{m}^{-2}$ for an $18 \mathrm{~d}$ period. Microcosms were initially supplied with detritus containing $23.2(\mathrm{~F})$ and $22.8(\mathrm{~A}) \mathrm{mBq} \mathrm{\textrm {m } ^ { - 2 }}$. Values in parenthesis are given as \% of added ${ }^{14} \mathrm{C}$ and sums up to recovery (\%) as given at the bottom. pw = porewater

\begin{tabular}{|lcccccrrrr|}
\hline & $\mathrm{DF}_{\text {surf }}$ & \multicolumn{1}{c}{$\mathrm{NF}_{\text {surf }}$} & \multicolumn{1}{c}{$\mathrm{DF}_{\text {sub }}$} & $\mathrm{NF}_{\text {sub }}$ & $\mathrm{DA}_{\text {surf }}$ & $\mathrm{NA}_{\text {surf }}$ & $\mathrm{DA}_{\text {sub }}$ & $\mathrm{NA}_{\text {sub }}$ \\
\hline${ }^{14} \mathrm{CO}_{2}$ flux & $4.88(21)$ & $5.89(25)$ & $2.74(12)$ & $6.77(29)$ & $1.87(8.2)$ & $2.63(12)$ & $0.56(2.5)$ & $2.54(11)$ \\
$\mathrm{DO}^{14}$ Cflux & $1.53(6.6)$ & $0.67(2.9)$ & $0.40(1.7)$ & $0.41(1.8)$ & $1.33(5.8)$ & $1.01(4.4)$ & $0.50(2.2)$ & $0.83(3.6)$ \\
$\mathrm{PO}^{14} \mathrm{Cleft}$ & $16.78(72)$ & $14.07(61)$ & $19.91(86)$ & $14.36(62)$ & $20.08(88)$ & $16.89(74)$ & $21.03(92)$ & $18.00(79)$ \\
$\mathrm{PO}^{14} \mathrm{Cworm}$ & - & $1.15(5.0)$ & - & $1.45(6.3)$ & - & $1.75(7.7)$ & - & $1.15(5.0)$ \\
$\mathrm{pwT}^{14} \mathrm{CO}_{2}$ & $0.02(0.1)$ & $0.02(0.1)$ & $0.61(2.6)$ & $0.02(0.1)$ & $0.01(0.1)$ & $0.01(0.1)$ & $0.22(1.0)$ & $0.02(0.1)$ \\
$\mathrm{pwDO}^{14} \mathrm{C}$ & $0.02(0.1)$ & $0.02(0.1)$ & $0.13(0.6)$ & $0.01(0.1)$ & $0.02(0.1)$ & $0.02(0.1)$ & $0.07(0.3)$ & $0.04(0.2)$ \\
Total & 23.23 & 21.82 & 23.79 & 23.02 & 23.31 & 22.32 & 22.38 & 22.58 \\
Recovery (\%) & 100 & 94 & 103 & 99 & 102 & 98 & 98 & 99 \\
\hline
\end{tabular}




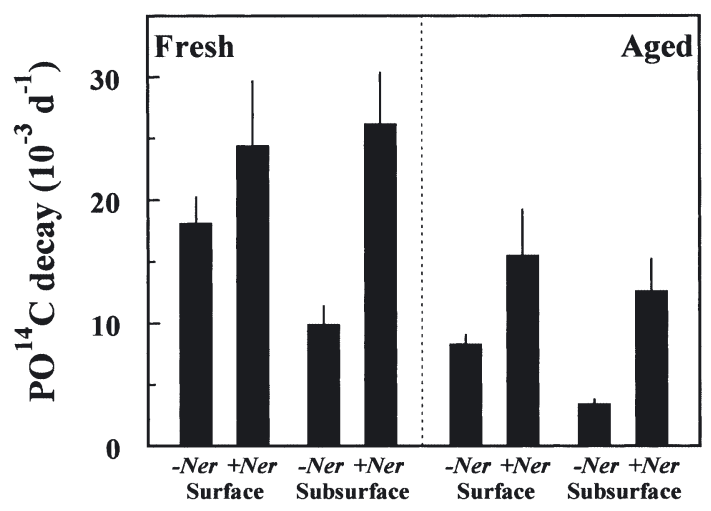

Fig. 3. Depth-integrated (0 to $10 \mathrm{~cm}$ ) decay of labeled particulate organic carbon $\left(\mathrm{PO}^{14} \mathrm{C}\right)$ in experimental cores with and without Nereis diversicolor (Ner). Values are given as decay constants $(\mathrm{k})$, assuming exponential decay $\left(G_{t}=G_{0} \exp [-\mathrm{k} t]_{\text {; }}\right.$ see 'Results' for details) over the $18 \mathrm{~d}$ period. Treatments with fresh and aged detritus are shown in the left and right panels, respectively. Values are given as the mean \pm SE of results from 3 replicate cores

of ${ }^{14} \mathrm{C}$ labeled detritus, as well as the irrigation activity of Nereis diversicolor. Defaunated sediments with fresh detritus $\left(\mathrm{DF}_{\text {surf }}\right.$ and $\left.\mathrm{DF}_{\text {sub }}\right)$ showed pronounced accumulation of $\mathrm{DO}^{14} \mathrm{C}$ around the deposited detritus (Fig. 4) in a pattern similar to the $\mathrm{PO}^{14} \mathrm{C}$ distribution (Fig. 2). The equivalent sediments with aged detritus exhibited much lower $\left(\mathrm{DA}_{\text {sub }}\right)$ or missing $\left(\mathrm{DA}_{\text {surf }}\right)$ peaks of porewater $\mathrm{DO}^{14} \mathrm{C}$. The treatments with $N$. diversicolor generally showed no accumulation of $\mathrm{DO}^{14} \mathrm{C}$ at

\section{$\mathrm{DO}^{14} \mathrm{C}\left(\mathrm{Bq} \mathrm{cm}^{-3}\right)$}
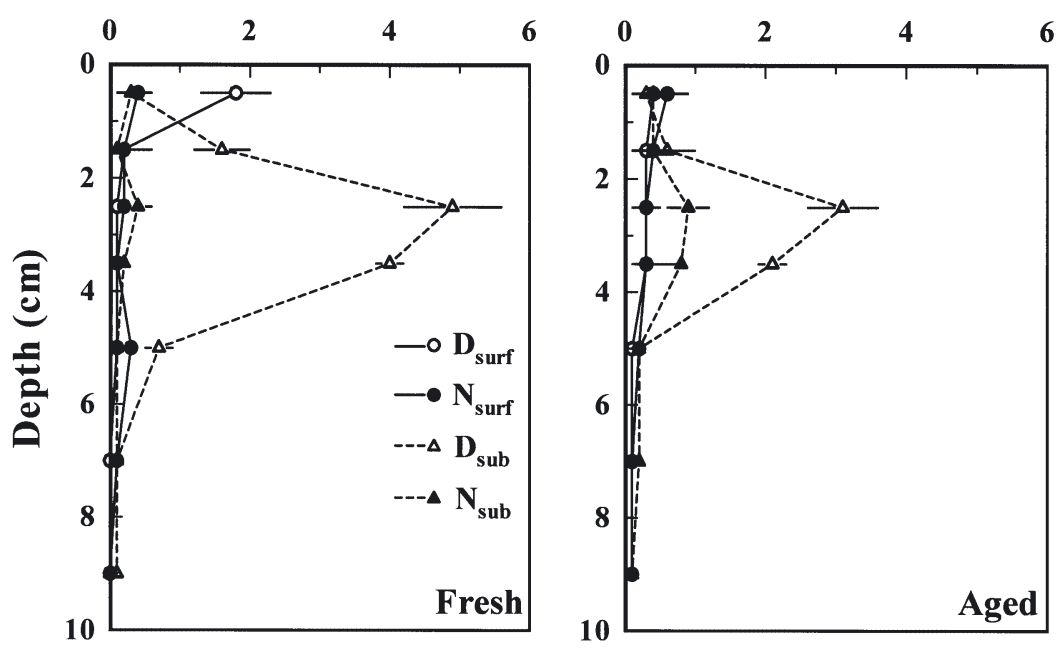

Fig. 4. Vertical distribution of labeled dissolved organic carbon $\left(\mathrm{DO}^{14} \mathrm{C}\right)$ in defaunated (D) and Nereis diversicolor (N) sediment with detritus added to the surface ( $($ surf $)$ and $3 \mathrm{~cm}$ below the surface $($ sub). Treatments with fresh and aged detritus are shown in the left and right panels, respectively. Results are given as the mean $\pm \mathrm{SE}$ of results from 3 replicate cores any depth, irrespective of detritus type and positioning. The concentrations in these sediments were similar to those of $\mathrm{DF}_{\text {surf }}$ and $\mathrm{DA}_{\text {surf }}$ below $1 \mathrm{~cm}$ depth. The only exception was a minor peak at 2 to $4 \mathrm{~cm}$ depth in $\mathrm{NA}_{\text {sub. }}$.

Significant accumulation of porewater $\mathrm{T}^{14} \mathrm{CO}_{2}$ was only evident in defaunated sediment with subsurface detritus ( $\mathrm{DF}_{\text {sub }}$ and $\mathrm{DA}_{\text {sub }}$ ) (Fig. 5). The peak concentration at 2 to $4 \mathrm{~cm}$ depth was 2 times higher in sediment with fresh detritus than with aged detritus. High levels of $\mathrm{T}^{14} \mathrm{CO}_{2}$ were not constrained to the zone of detritus deposition, but extended throughout the examined sediment depth. All other treatments only showed trace amounts of porewater $\mathrm{T}^{14} \mathrm{CO}_{2}$ in the sediment. The depth-integrated accumulation of dissolved ${ }^{14} \mathrm{C}$ compounds in the porewater was insignificant compared to the initially added $\mathrm{PO}^{14} \mathrm{C}$ (Table 2). Except for $\mathrm{T}^{14} \mathrm{CO}_{2}$ accumulation in defaunated sediment with subsurface detritus $\left(2.6 \%\right.$ in $\mathrm{DF}_{\text {sub }}$ and $1.0 \%$ in $\left.\mathrm{DA}_{\text {sub }}\right)$, the dissolved ${ }^{14} \mathrm{C}$ pools accounted for much less than $1 \%$ of the added $\mathrm{PO}^{14} \mathrm{C}$.

\section{Flux of labeled dissolved carbon $\left(\mathrm{DO}^{14} \mathrm{C}\right.$ and $\left.\mathrm{T}^{14} \mathrm{CO}_{2}\right)$}

The release of $\mathrm{DO}^{14} \mathrm{C}$ and $\mathrm{T}^{14} \mathrm{CO}_{2}$ from the sediment showed no specific pattern with time in any of the treatments after the first $3 \mathrm{~d}$ incubation period. The daily rates are therefore presented as the average of 5 time points, each consisting of a $3 \mathrm{~d}$ incubation period (Fig. 6). The initial $3 \mathrm{~d}$ incubation period is excluded due to handling inconsistencies. The impact of detritus quality on $\mathrm{DO}^{14} \mathrm{C}$ flux was generally insignificant, whereas the efflux of $\mathrm{T}^{14} \mathrm{CO}_{2}$ was 2 to 5 times higher in treatments with fresh than aged detritus. The release of $\mathrm{DO}^{14} \mathrm{C}$ was highest when detritus was added to the surface of defaunated sediment, but $\mathrm{DO}^{14} \mathrm{C}$ release, cumulated over the entire experimental period in these treatments, only accounted for $6.6\left(\mathrm{DF}_{\text {surf }}\right)$ and $5.9 \%$ $\left(\mathrm{DA}_{\text {surf }}\right)$ of the initially added $\mathrm{PO}^{14} \mathrm{C}$ (Table 2). The presence of Nereis diversicolor reduced the efflux of $\mathrm{DO}^{14} \mathrm{C}$ from surface-deposited detritus by 56 ( $\left.\mathrm{NF}_{\text {surf }}\right)$ and $24 \%\left(\mathrm{NA}_{\text {surf }}\right)$. The $\mathrm{DO}^{14} \mathrm{C}$ release from subsurface-deposited detritus was only 26 $\left(\mathrm{DF}_{\text {sub }}\right)$ and $38 \%\left(\mathrm{DA}_{\text {sub }}\right)$ of that from surface-deposited detritus. There was no impact of $N$. diversicolor on $\mathrm{DO}^{14} \mathrm{C}$ flux from subsurface-deposited fresh detritus $\left(\mathrm{NF}_{\text {sub }}\right)$, whereas a $66 \%$ increase occurred for aged detritus $\left(\mathrm{NA}_{\mathrm{sub}}\right)$. Despite the limited or even negative effect of $N$. diversi- 
$\mathrm{T}^{14} \mathrm{CO}_{2}\left(\mathrm{~Bq} \mathrm{~cm}{ }^{-3}\right)$
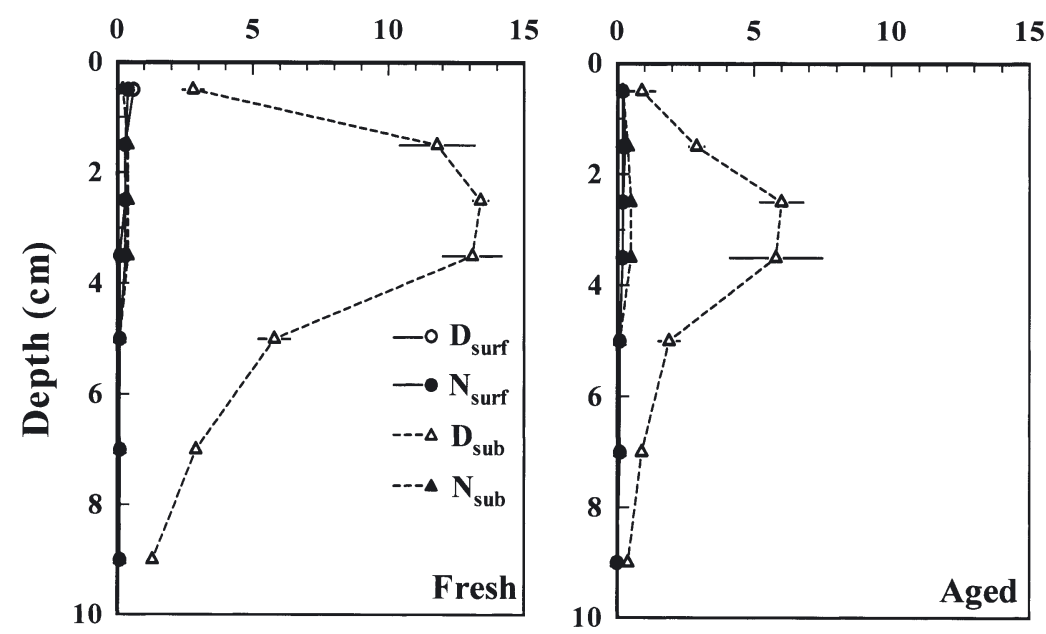

Fig. 5. Vertical distribution of labeled total $\mathrm{CO}_{2}\left(\mathrm{~T}^{14} \mathrm{CO}_{2}\right)$ in defaunated (D) and Nereis diversicolor $(\mathrm{N})$ sediment with detritus added to the surface (surf) and $3 \mathrm{~cm}$ below the surface (sub). Treatments with fresh and aged detritus are shown in the left and right panels, respectively. Results are given as the mean $\pm \mathrm{SE}$ of results from 3 replicate cores

color, direct excretion by the worms accounted for a substantial fraction of the $\mathrm{DO}^{14} \mathrm{C}$ efflux (Table 3), particularly when fresh detritus was added to the sediment (70 to $90 \%$ ).

The pattern of $\mathrm{T}^{14} \mathrm{CO}_{2}$ release in the various treatments (Fig. 6) was a mirror image of the $\mathrm{PO}^{14} \mathrm{C}$ decay (Fig. 3), indicating that most of the lost detrital carbon was mineralized completely. The cumulated $\mathrm{T}^{14} \mathrm{CO}_{2}$ release over the entire experimental period accounted

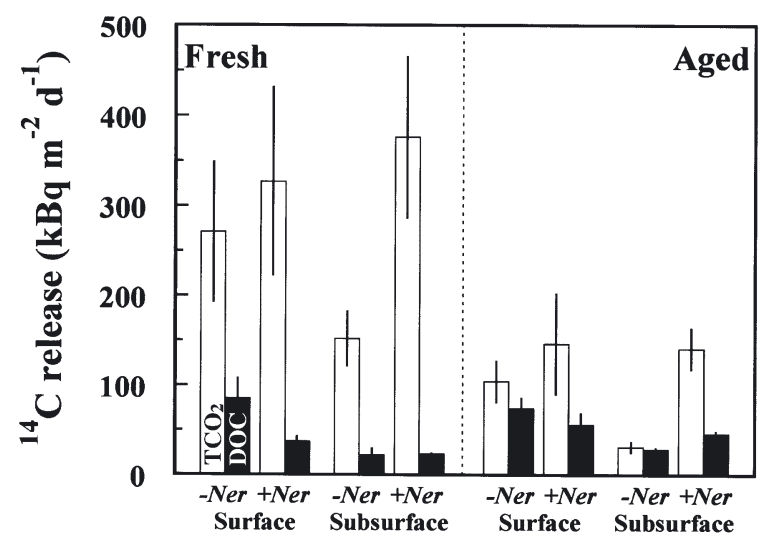

Fig. 6. Daily release of labeled total $\mathrm{CO}_{2}\left(\mathrm{~T}^{14} \mathrm{CO}_{2}\right)$ and dissolved organic carbon $\left(\mathrm{DO}^{14} \mathrm{C}\right)$ from the sediment in experimental cores with and without Nereis diversicolor (Ner). Open and solid bars represent $\mathrm{T}^{14} \mathrm{CO}_{2}$ and $\mathrm{DO}^{14} \mathrm{C}$, respectively. Treatments with fresh and aged detritus are shown in the left and right panels, respectively. Values are given as average \pm SE of 5 time points, each based on a $3 \mathrm{~d}$ incubation period for 12 to $29 \%$ for fresh detritus and 3 to $12 \%$ for aged detritus of the initially added $\mathrm{PO}^{14} \mathrm{C}$ (Table 2). The highest release occurred in sediment with fresh detritus and Nereis diversicolor $\left(\mathrm{NF}_{\text {surf }}\right.$ and $\mathrm{NF}_{\text {sub }}$ ), and the lowest in defaunated sediment with aged detritus $\left(\mathrm{DA}_{\text {surf }}\right.$ and $\left.\mathrm{DA}_{\mathrm{sub}}\right)$. Addition of detritus to the surface of defaunated sediment increased the $\mathrm{T}^{14} \mathrm{CO}_{2}$ efflux by 78 $\left(\mathrm{DF}_{\text {surf }}\right)$ and $234 \%\left(\mathrm{DA}_{\text {surf }}\right)$ compared with subsurface-deposited detritus. The relative impact of $N$. diversicolor on $\mathrm{T}^{14} \mathrm{CO}_{2}$ release from surface-deposited detritus appeared independent of detritus quality and was limited to 21 ( $\left.\mathrm{NF}_{\text {surf }}\right)$ and $41 \%\left(\mathrm{NA}_{\text {surf }}\right)$, whereas a more pronounced faunal effect was evident for subsurface-deposited detritus, particularly for aged material ( $\mathrm{NA}_{\text {sub }}$, Table 4$)$, with a $354 \%$ increase compared with $147 \%$ for fresh material $\left(\mathrm{NF}_{\text {sub }}\right)$. Respiration of ingested ${ }^{14} \mathrm{C}$-labeled detritus by $N$. diversicolor accounted for 23 to 31 and 12 to $13 \%$ of the $\mathrm{T}^{14} \mathrm{CO}_{2}$ release when fresh and aged detritus was added, respectively (Table 3 ).

\section{Total $\mathrm{CO}_{2}$ flux}

The release of $\mathrm{TCO}_{2}$ from the sediment (Fig. 7) followed the same general pattern among treatments as found for $\mathrm{PO}^{14} \mathrm{C}$ decay (Fig. 3) and $\mathrm{T}^{14} \mathrm{CO}_{2}$ release (Fig. 6). Thus, Nereis diversicolor increased $\mathrm{TCO}_{2}$ flux by $51\left(\mathrm{~F}_{\text {surf }}\right)$ and $149 \%\left(\mathrm{~A}_{\text {surf }}\right.$, Table 4$)$. Respiration by worms accounted for 34 to $49 \%$ of the $\mathrm{TCO}_{2}$ efflux (Table 3), with the highest contribution occurring when fresh detritus was added to the surface. However, the difference in $\mathrm{TCO}_{2}$ release between various treatments (fresh vs aged detritus and surface vs subsurface deposition) containing $N$. diversicolor was small, and in defaunated treatments there was only a noteworthy difference between fresh and aged detritus $\left(\mathrm{DF}_{\text {surf }}: \mathrm{DA}_{\text {surf }}=1.6\right)$ when added to the surface.

Table 3. Contribution of Nereis diversicolor metabolism to the release of dissolved carbon species from the sediment. Results are given as \% of total efflux

\begin{tabular}{|lccc|}
\hline & $\mathrm{CO}_{2}$ & ${ }^{14} \mathrm{CO}_{2}$ & $\mathrm{DO}^{14} \mathrm{C}$ \\
\hline $\mathrm{NF}_{\text {surf }}$ & 48.7 & 31.2 & 67.6 \\
$\mathrm{NF}_{\text {sub }}$ & 33.6 & 23.4 & 91.3 \\
$\mathrm{NA}_{\text {surf }}$ & 36.0 & 12.3 & 21.4 \\
$\mathrm{NA}_{\text {sub }}$ & 35.0 & 12.8 & 26.1 \\
\hline
\end{tabular}


Table 4. Stimulation of sediment rates (total $\mathrm{CO}_{2}$ and ${ }^{14} \mathrm{CO}_{2}$ flux, microbially derived $\mathrm{CO}_{2}$ and ${ }^{14} \mathrm{CO}_{2}$ flux [when worm metabolism is substracted], and $\mathrm{PO}^{14} \mathrm{C}$ decay) by the presence of Nereis diversicolor. Results are given as \% change relative to the corresponding treatments without $N$. diversicolor. Abbreviations as in Table 1

\begin{tabular}{|lccccc|}
\hline & Total $\mathrm{CO}_{2}$ & Total ${ }^{14} \mathrm{CO}_{2}$ & Micr. $\mathrm{CO}_{2}$ & Micr. ${ }^{14} \mathrm{CO}_{2}$ & PO $^{14} \mathrm{C}$ decay \\
\hline $\mathrm{F}_{\text {surf }}$ & 51 & 21 & -23 & -17 & 35 \\
$\mathrm{~F}_{\text {sub }}$ & 115 & 147 & 42 & 89 & 165 \\
$\mathrm{~A}_{\text {surf }}$ & 149 & 41 & 59 & 23 & 87 \\
$\mathrm{~A}_{\text {sub }}$ & 128 & 354 & 49 & 297 & 270 \\
\hline
\end{tabular}

Table 5. Contribution of added and indigenous detritus to the release of $\mathrm{TCO}_{2}$ from the sediment. Values for added detritus are estimated by converting measured $\mathrm{T}^{14} \mathrm{CO}_{2}$ release to $\mathrm{TCO}_{2}$

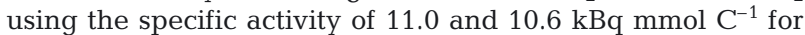
fresh and aged detritus, respectively. Values for indigenous detritus are calculated as the difference between measured $\mathrm{TCO}_{2}$ release (Fig. 7) and estimated contribution from added detritus. The units are $\mathrm{mmol} \mathrm{m} \mathrm{m}^{-2} \mathrm{~d}^{-1}$ and values in parentheses indicate the percentage contribution. Abbreviations as in Table 1

\begin{tabular}{|lrc|}
\hline & Added detritus & Indigenous detritus \\
\hline $\mathrm{DF}_{\text {surf }}$ & $25.3(46)$ & $29.2(54)$ \\
$\mathrm{NF}_{\text {surf }}$ & $30.6(37)$ & $51.7(63)$ \\
$\mathrm{DF}_{\text {sub }}$ & $14.2(30)$ & $33.5(70)$ \\
$\mathrm{NF}_{\text {sub }}$ & $35.1(34)$ & $67.5(66)$ \\
$\mathrm{DA}_{\text {surf }}$ & $9.7(28)$ & $24.4(72)$ \\
$\mathrm{NA}_{\text {surf }}$ & $13.6(16)$ & $71.3(84)$ \\
$\mathrm{DA}_{\text {sub }}$ & $2.9(8)$ & $34.7(92)$ \\
$\mathrm{NA}_{\text {sub }}$ & $13.2(15)$ & $72.9(85)$ \\
\hline
\end{tabular}

The contribution of carbon from ${ }^{14} \mathrm{C}$-labeled detritus to the $\mathrm{TCO}_{2}$ efflux can be estimated as the measured $\mathrm{T}^{14} \mathrm{CO}_{2}$ flux divided by the specific activity of the detritus. The higher reactivity of organic carbon in fresh detritus is substantiated by a 30 to $46 \%$ contribution to the $\mathrm{TCO}_{2}$ flux (Table 5). Although aged detritus contributed only 8 to $28 \%$ to the $\mathrm{TCO}_{2}$ flux, it was still more reactive on a weight basis than the indigenous detritus, as the added detritus only accounted for 3\% of the total organic pool. The detritus contribution to $\mathrm{TCO}_{2}$ flux was highest when the detritus was added to the surface of defaunated sediment, intermediate for bioturbated sediments, irrespective detritus positioning, and lowest when detritus was buried into defaunated sediment.

\section{DISCUSSION}

The aging procedure employed in the present study apparently removed a large fraction of the most labile pool of particulate organic carbon in Fucus serratus detritus, as indicated by 30 to $60 \%$ lower reactivity of aged than fresh detritus in the various treatments (Fig. 3). A similar change in reactivity has been reported for lignin-rich barley hay after $50 \mathrm{~d}$ of aging, whereas the protein-rich diatoms apparently retain almost the same reactivity even after $40 \mathrm{~d}$ of aging (Kristensen \& Holmer 2001). Decay characteristics of various materials are therefore operationally defined, and the final reactivity after aging depends on the type of substrate used as well as the duration of decay. As most organic materials exhibit an exponentially decreasing decay pattern through time (Westrich \& Berner 1984), the actual attenuation is very dependent on the chemical composition of the substrate and the conditions under which the processes proceed (Fenchel et al. 1998). In any case, the results obtained in the present study suggest that the 2-fold difference in reactivity between fresh and aged $F$. serratus detritus is sufficient to determine the differential impact of burial and bioturbation on decay dynamics of labile and refractory components.

Although much of the leachable and fast-degrading DOC fraction in the Fucus serratus detritus was removed during the initial mincing and sieving procedure, the $\mathrm{DO}^{14} \mathrm{C}$ release after deposition at the sediment surface still accounted for up to 30 and $90 \%$ of the $\mathrm{T}^{14} \mathrm{CO}_{2}$ release from fresh and aged detritus,

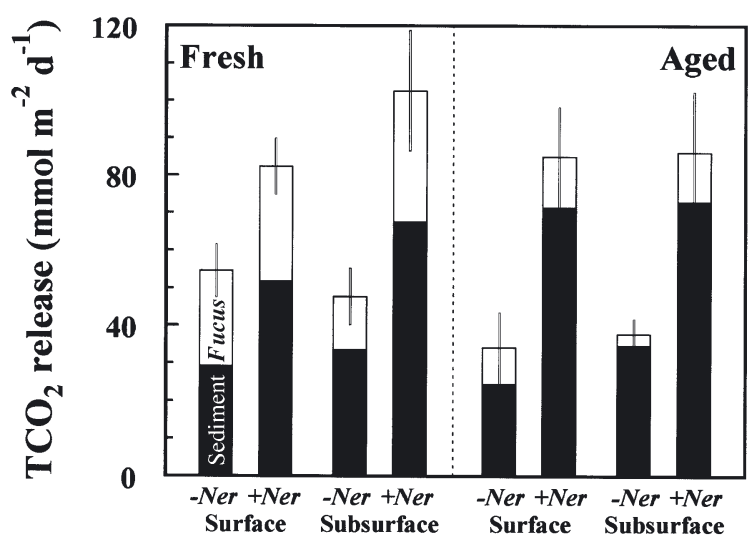

Fig. 7. Daily release of total $\mathrm{CO}_{2}\left(\mathrm{TCO}_{2}\right)$ from the sediment in experimental cores with and without Nereis diversicolor (Ner). The upper open part of the bars represents $\mathrm{TCO}_{2}$ derived from added Fucus serratus detritus, and is estimated from $\mathrm{T}^{14} \mathrm{CO}_{2}$ data (Fig. 6) and the specific activity of the detritus. The lower solid part of the bars represents $\mathrm{TCO}_{2}$ derived from the indigenous organic matter in the sediment. Treatments with fresh and aged detritus are shown in the left and right panels, respectively. Results are given as the mean $\pm \mathrm{SE}$ of results from 3 replicate cores 
respectively (Fig. 6). Much of this may be of secondary origin and result from dissolution of the particulate phase by the action of microbial exoenzymes (Madigan et al. 2002), with a significant contribution from excretion by worms when they are present. However, oxidation by the microbial communities within the sediment reduced the contribution of $\mathrm{DO}^{14} \mathrm{C}$ efflux to 10 and $40 \%$ of the $\mathrm{T}^{14} \mathrm{CO}_{2}$ efflux when detritus was deposited into the sediment. It is interesting that the absolute rates of $\mathrm{DO}^{14} \mathrm{C}$ release were almost identical in treatments with fresh and aged detritus. Consequently, the $\mathrm{DO}^{14} \mathrm{C}$ released from fresh detritus must be more available to respiring microorganisms than $\mathrm{DO}^{14} \mathrm{C}$ released from aged detritus. The pool of more refractory $\mathrm{DO}^{14} \mathrm{C}$ that escapes microbial oxidation before it is released to the overlying water, on the other hand, is of comparable size, irrespective of detritus type. Thus, the balance between net production of labile and refractory DOC and the time allowed for oxidation within the sediment determines the efflux of DOC, as argued by Burdige (2002).

\section{Fate of surface-deposited detritus}

As oxygen usually penetrates a few mm by diffusion into the surface of most coastal sediments (Jørgensen \& Revsbech 1985), the initial microbial degradation of detritus at the sediment surface should largely be mediated by aerobic bacteria. The decay rates of fresh and aged Fucus serratus detritus deposited at the surface in the absence of Nereis diversicolor (decay constants: $\mathrm{k}=18 \times 10^{-3}$ and $8 \times 10^{-3} \mathrm{~d}^{-1}$, respectively; Fig. 3) are comparable to those previously reported for non-leachable particulate plant materials in oxic marine sediments (10 to $20 \times 10^{-3} \mathrm{~d}^{-1}$; Kristensen \& Holmer 2001, D'Andrea et al. 2002), and substantiates that a significant fraction of surface-deposited detritus in the defaunated sediment was indeed degraded aerobically.

The 50 to $150 \%$ enhancement of $\mathrm{TCO}_{2}$ efflux by Nereis diversicolor (Table 4) are within the range previously found for this species in sandy coastal sediments (Hansen \& Kristensen 1997, Banta et al. 1999, Heilskov \& Holmer 2001). The larger direct contribution of respiration by $N$. diversicolor to the $\mathrm{TCO}_{2}$ efflux from the sediment (35 to $50 \%$, Table 3 ) than values of $\sim 20 \%$ as previously reported (Banta et al. 1999, Christensen et al. 2000) may be due to the relatively large biomass of worms added to the microcosms (565 $\mathrm{g}$ wet $\mathrm{wt}^{-2}$ ) compared to the natural abundance (80 to $230 \mathrm{~g}$ wet wt $\mathrm{m}^{-2}$ at Fællesstrand; Kristensen 1993). However, the faunal impact on degradation of Fucus serratus detritus deposited at the surface was modest, as the $\mathrm{T}^{14} \mathrm{CO}_{2}$ release was only increased by ca. 20 and $40 \%$; and $\mathrm{PO}^{14} \mathrm{C}$ removal stimulated by ca. 35 and $90 \%$ (decay constants of $24 \times 10^{-3} \mathrm{~d}^{-1}$ and $\left.15 \times 10^{-3} \mathrm{~d}^{-1}\right)$ for fresh and aged detritus, respectively (Table 4 ). As the indigenous detritus accounted for 50 to $60 \%$ of the total flux with fresh detritus and 70 to $80 \%$ with aged detritus added to the surface (Table 5), the enhancement of $\mathrm{TCO}_{2}$ efflux by $N$. diversicolor was primarily driven by degradation of this carbon source (80 and 190\% increase, respectively). The mechanism by which $N$. diversicolor affects surface-deposited detritus is primarily related to feeding and burrowing activities, as indicated by the rapid displacement of $F$. serratus detritus from the surface and down to at least $5 \mathrm{~cm}$ depth (Fig. 2). N. diversicolor either pulls edible detritus into burrows for later ingestion, or ingests the detritus right at the surface (Goerke 1971, Esselink \& Zwarts 1989, Thomas \& Blair 2002). The undigested remains are later defecated within burrows or occasionally at the surface.

Ingestion of labeled detritus by Nereis diversicolor clearly occurred, as 5 (fresh) and $8 \%$ (aged) of the recovered ${ }^{14} \mathrm{C}$ at the end was directly associated with worms (Table 2). If all this ${ }^{14} \mathrm{C}$ was incorporated and transformed into new worm tissue with an efficiency of $25 \%$ (Cammen 1980), worm respiration should account for 16 and $24 \%$ of the added fresh and aged Fucus serratus carbon, respectively. Since these estimates (equivalent to 58 and $200 \%$ of the measured $\mathrm{T}^{14} \mathrm{CO}_{2}$ efflux) exceed the measured contribution of $N$. diversicolor respiration (31 and 12\%, respectively, Table 3), much of the $\mathrm{PO}^{14} \mathrm{C}$ associated with $N$. diversicolor is probably undigested $F$. serratus detritus remaining in the intestine. Based on the measured respiration and the incorporation efficiency mentioned above, the amount of $F$. serratus carbon converted into $N$. diversicolor tissue during the $18 \mathrm{~d}$ period was only 2.8 and $0.5 \%$ of the added fresh and aged detritus, respectively. For comparison, Josefson et al. (2002) found that deposit-feeders incorporate ca. $5 \%$ of ${ }^{14} \mathrm{C}$-labeled fresh diatoms over a period of $54 \mathrm{~d}$. Undigested material in the intestine must therefore account for 47 and $94 \%$ of the $F$. serratus carbon recovered from $N$. diversicolor. In other words, each $400 \mathrm{mg}$ worm contained $8 \mathrm{mg}$ fresh detritus or $25 \mathrm{mg}$ aged detritus in the intestine at the end of the experiment. Although deposit feeders' digestive fluids are better able to solubilize sedimentary food substrates than are sedimentary extracellular enzymes (Mayer et al. 1997), the low assimilation and incorporation of aged detritus substantiates that the lower microbial degradability of aged compared to fresh detritus also corresponds to the digestibility of these substrates within worm intestines. Accordingly, Ahrens et al. (2001) found that N. succinea assimilated live phytoplankton with an efficiency of 55 to $95 \%$, while bulk sediment organic matter was assimilated with an efficiency of only 5 to $18 \%$. 
Competition for food between detritivores and bacteria is known to occur after deposition of fresh detritus to sediment systems (Kristensen et al. 1992, Findlay \& Watling 1998). Tenore et al. (1982) suggested that deposit feeders and bacteria compete for labile detritus, while bacteria regulate the availability of more refractory detritus to animals. A competitive interaction is also apparent between Nereis diversicolor and microorganisms when microbial degradation in faunated sediments is estimated by subtracting the measured metabolic contribution of $N$. diversicolor from the total carbon oxidation, particularly where fresh Fucus serratus is added to the surface (Table 4). Despite an increase in the total degradation of fresh $F$. serratus detritus, competition with $N$. diversicolor reduces the microbial contribution by $\sim 20 \%$ compared with defaunated sediment. Direct feeding on F. serratus, and subsequent respiration by $N$. diversicolor, is therefore responsible for the increased $\mathrm{T}^{14} \mathrm{CO}_{2}$ release in this treatment. The modest but significant $20 \%$ increase in microbial oxidation of carbon from aged $F$. serratus in faunated sediment may be a consequence of the feeding activities by $N$. diversicolor. Maceration during ingestion, passage through the gut, and contact with digestive enzymes probably facilitate microbial attacks on otherwise refractory compounds after defecation. A similar increase in microbial degradability of refractory detritus by macrofaunal feeding activities has been observed on several occasions (Hargrave 1976, Horng \& Taghon 2001, Kristensen \& Pilgaard 2001). However, the stimulatory effect of $N$. diversicolor on microbial decay of aged detritus may also partly be due to increased oxygen exposure resulting from worm activities, such as irrigation (see next section below).

\section{Fate of subsurface-deposited detritus}

Microbial decay of detritus deposited $3 \mathrm{~cm}$ into defaunated sediment must occur by hydrolysis/ fermentation coupled with anaerobic respiration (Fenchel et al. 1998). The electron acceptor in question is primarily $\mathrm{SO}_{4}{ }^{2-}$, because $\mathrm{O}_{2}$ and $\mathrm{NO}_{3}{ }^{-}$do not penetrate to $3 \mathrm{~cm}$ depth, and most reducible $\mathrm{Mn}$ and Fe disappears within a few days in anoxic sandy sediment devoid of macrofauna (Epping \& Helder 1997, Meyer et al. 2001, Kristiansen et al. 2002). The decay constant of subsurface deposited fresh Fucus serratus detritus $\left(\mathrm{k}=9.9 \times 10^{-3} \mathrm{~d}^{-1}\right)$ in defaunated sediment is almost 3 times higher than that of aged detritus $\left(3.4 \times 10^{-3} \mathrm{~d}^{-1}\right.$, Fig. 3). Comparable decay constants have previously been found for macrophyte detritus under anoxic conditions in laboratory experiments (Kristensen \& Holmer 2001) and for metabolizable particulate organic matter in anoxic Chesapeake Bay sediments (Roden \& Tuttle 1996).

The decay rates for both types of detritus in anoxic subsurface sediment are about half of those obtained for detritus deposited in oxic surface sediment. If enhanced decay at the surface is caused by exposure to oxygen, the observed difference is relatively modest compared to the results of Kristensen \& Holmer (2001). They found that the difference between oxic and anoxic decay of fresh and aged hay was a factor of 2 and 5, whereas the difference was a factor of 7 and $>10$ for fresh and aged diatoms. Hulthe et al. (1998) observed a similar difference between oxic and anoxic degradation of sediment detritus under in situ conditions. Furthermore, the trend for relatively faster decay of aged than fresh Fucus serratus detritus at the sediment surface compared with subsurface-deposited detritus is less than the differential oxygen effect found by Kristensen \& Holmer (2001). These discrepancies suggest that surface-deposited detritus was not completely exposed to oxygen. The penetration of oxygen by diffusion from the overlying water was probably limited to the uppermost layer (i.e. less than $1 \mathrm{~mm}$ ) of the actively degrading surface detritus, while the remainder was exposed to anoxic conditions. Degradation utilizing other electron acceptors than oxygen at rates comparable to those in subsurface sediment may therefore have prevailed in the deeper part of the detritus layer near the sediment surface, as previously observed for defaunated sediments covered by layers of Ulva lactuca (Nedergaard et al. 2002).

The presence of Nereis diversicolor in sediment with subsurface-deposited Fucus serratus detritus had a dramatic effect on detritus decay. The $\mathrm{PO}^{14} \mathrm{C}$ decay constants increased by 160 and $270 \%\left(26 \times 10^{-3} \mathrm{~d}^{-1}\right.$ and $13 \times 10^{-3} \mathrm{~d}^{-1}$ ) for fresh and aged detritus, respectively, and reached levels comparable to faunated sediment with surface-deposited detritus. A similar trend was observed for $\mathrm{T}^{14} \mathrm{CO}_{2}$ release, showing 150 and $350 \%$ increase, respectively. However, the distinct effect of $N$. diversicolor on degradation of fresh and aged detritus buried in the sediment was not reflected in the release of $\mathrm{TCO}_{2}$, which was only enhanced by 115 and $130 \%$, respectively. As the $\mathrm{TCO}_{2}$ release was mostly derived from indigenous detritus (65 to $90 \%$, Table 5), the large enhancement of $\mathrm{T}^{14} \mathrm{CO}_{2}$, particularly for aged detritus, is concealed by a more modest 100 to $110 \%$ increase in degradation of indigenous detritus.

Burrowing and feeding by Nereis diversicolor affect the distribution and degradation of subsurfacedeposited detritus. The distinct inventories of $\mathrm{PO}^{14} \mathrm{C}$ observed at the location of deposition in defaunated sediment are not evident in faunated sediment, where $\mathrm{PO}^{14} \mathrm{C}$ is mixed more or less homogeneously into the 
upper $4 \mathrm{~cm}$. Particle-reworking activities primarily enhance the microbial degradation when detritus is occasionally exposed to oxygen at the surface. Otherwise the particles are just displaced within the sediment column and only affect the internal distribution of bacterial numbers and activity (Stoeck \& Kröncke 2001) without any significant effect on the overall degradation. $N$. diversicolor have certainly also selectively ingested subsurface deposited detritus, as 6 and $5 \%$ of the total recovery of ${ }^{14} \mathrm{C}$ at the end of the experiment was associated with the worms (Table 2). From the measured respiratory release of ${ }^{14} \mathrm{CO}_{2}$ by $N$. diversicolor (23 and $13 \%$ of the total release from the sediment in treatments with fresh and aged detritus), and using the same calculations as above, ca. 60 to $70 \%$ of ${ }^{14} \mathrm{C}$ associated with $N$. diversicolor was undigested remains in the intestine. This is equivalent to ca. $12 \mathrm{mg}$ detritus of both types in the intestine of a $400 \mathrm{mg}$ worm.

As the direct contribution by Nereis diversicolor feeding, assimilation and respiration appears comparable in sediments with surface and subsurface detritus, most of the stimulation by $N$. diversicolor on the decay of subsurface detritus must be related to indirect effects on microbial activities. The most likely cause for the enhanced microbial decay of subsurface-deposited detritus is related to the vigorous burrow irrigation conducted by $N$. diversicolor. Its intermittent and forceful irrigation injects oxygen into subsurface sediment and removes potentially toxic metabolites from the porewater (Kristensen 2001). The strong advective transport caused by $N$. diversicolor irrigation is evident from the porewater profiles of $\mathrm{T}^{14} \mathrm{CO}_{2}$ (Fig. 5) and $\mathrm{DO}^{14} \mathrm{C}$ (Fig. 4). The distinct and large subsurface peaks of these solutes observed in defaunated sediment have almost disappeared in the faunated sediment. A similar rapid exchange of porewater solutes has been observed in a variety of sediments affected by infaunal irrigation (e.g. Banta et al. 1999, D'Andrea et al. 2002). The resulting injection of oxygen and associated redox oscillations are important for the heterotrophic microbial communities and enhances decomposition of particularly aged detritus buried in otherwise anoxic sediment (Aller 1994, Hulthe et al. 1998, Kristensen 2000). In accordance, the microbial decay of fresh and aged detritus buried in the sediment was increased by 90 and $300 \%$, respectively. The much stronger enhancement of microbial degradation of aged than fresh detritus by oxidizing activities of $N$. diversicolor fully supports the predictions of Kristensen et al. (1992) and Kristensen \& Holmer (2001).

The several-fold higher stimulation of microbial decay of aged detritus substantiates the importance of burrow irrigation for degradation of old and partly degraded detritus in sediments. If no injection of oxy- gen occurs, a larger fraction of these refractory compounds will remain undegraded and be buried permanently in sediments. As a consequence, the capacity for organic matter decomposition is increased dramatically in irrigated sediments.

\section{CONCLUSIONS}

Nereis diversicolor significantly increases the decay of fresh and aged Fucus serratus detritus in sediment. The direct and indirect effects of $N$. diversicolor on microbial activities are strongly dependent on the quality (age) of the detritus and its position (depth) in the sediment, and constrain the role of various activities (e.g. burrowing, feeding and irrigation). The impact of burrowing and feeding is related to redistribution of detritus and competition with the microbial community, as well as ingestion, assimilation and respiration by the animals. When detritus is moved between the oxic surface layers and anoxic subsurface layers of the sediment during burrowing, microbial decomposition shifts between an inefficient anaerobic and a more efficient aerobic metabolism. The microbial contribution to the decay of fresh detritus positioned at the surface is actually affected negatively by competition from $N$. diversicolor, when it feeds directly on this attractive detritus and associated microorganisms. No such competition occurs in the presence of aged detritus. On the contrary, microbial degradability of aged materials is enhanced after passage through the gut of $N$. diversicolor. Irrigation, on the other hand, primarily stimulates the decay of aged detritus buried into the sediment. The irrigation impact is of indirect nature and is caused by stimulation of microbial activity due to the increased availability of oxygen in subsurface sediment. The generally stronger enhancement of aged than fresh detritus decay by activities of $N$. diversicolor corresponds with the contention that the effect is primarily caused by injection of oxygen via irrigation, as argued by Kristensen \& Holmer (2001), and fully supports the original ideas of Kristensen et al. (1992).

Acknowledgements. We thank $\mathrm{H}$. Brandt for technical assistance. This work was supported by the Danish Science Research Foundation (Grant \#21020463).

\section{LITERATURE CITED}

Ahrens MJ, Hertz J, Lamoureux EM, Lopez GR, McElroy AE, Brownawell BJ (2001) The effect of body size on digestive chemistry and absorption efficiencies of food and sediment-bound organic contaminants in Nereis succinea (Polychaeta). J Exp Mar Biol Ecol 263:185-209 
Aller RC (1994) Bioturbation and remineralization of sedimentary organic matter: effects of redox oscillations. Chem Geol 114:331-345

Aller RC, Aller JY (1998) The effect of biogenic irrigation intensity and solute exchange on diagenetic reaction rates in marine sediments. J Mar Res 56:905-936

Banta GT, Holmer M, Jensen MH, Kristensen E (1999) The effect of two polychaete worms, Nereis diversicolor and Arenicola marina, on aerobic and anaerobic decomposition in organic-poor marine sediment. Aquat Microb Ecol 19:189-204

Berner RA (1980) Early diagenesis, a theoretical approach. Princeton University Press, Princeton, NJ

Burdige DJ (2002) Sediment pore waters. In: Hansell D, Carlson C (eds) Biogeochemistry of marine dissolved organic matter. Academic Press, New York, p 611-663

Cammen LM (1980) The significance of microbial carbon in the nutrition of the deposit feeding polychaete Nereis succinea. Mar Biol 61:9-20

Christensen B, Vedel A, Kristensen E (2000) Carbon and nitrogen fluxes in sediment inhabited by suspensionfeeding (Nereis diversicolor) and non-suspension-feeding ( $N$. virens) polychaetes. Mar Ecol Prog Ser 192: 203-217

D'Andrea AF, Aller RC, Lopez GR (2002) Organic matter flux and reactivity on a South Carolina sandflat: the impacts of porewater advection and macrobiological structures. Limnol Oceanogr 47:1056-1070

Davey JT (1994) The architecture of the burrow of Nereis diversicolor and its quantification in relation to sediment-water exchange. J Exp Mar Biol Ecol 179:115-129

Epping EHG, Helder W (1997) Oxygen budgets calculated from in situ oxygen microprofiles for northern Adriatic sediments. Cont Shelf Res 17:1737-1764

Esselink P, Zwarts L (1989) Seasonal trend in burrow depth and tidal variation in feeding activity of Nereis diversicolor. Mar Ecol Prog Ser 56:243-254

Fenchel T, King GM, Blackburn TH (1998) Bacterial biogeochemistry: the ecophysiology of mineral cycling. Academic Press, San Diego

Findlay RH, Watling L (1998) Seasonal variation in the structure of a marine benthic microbial community. Microb Ecol 36:23-30

Findlay S, Tenore K (1982) Nitrogen source for a detritivore: detritus substrate versus associated microbes. Science 218:371-373

Furukawa Y, Bentley SJ, Lavoie DL (2001) Bioirrigation modeling in experimental benthic mesocosms. J Mar Res 59: $417-452$

Goerke H (1971) Die Ernährungsweise der Nereis-Arten (Polychaeta, Nereidae) der deutschen Küsten. Veroeff Inst Meeresforsch Bremerhav 13:1-50

Hall POJ, Aller RC (1992) Rapid small-volume flow injection analysis for $\mathrm{SCO}_{2}$ and $\mathrm{NH} 4^{+}$in marine and freshwaters. Limnol Oceanogr 37:1113-1118

Hansen K, Kristensen E (1997) The impact of macrofaunal recolonization on benthic metabolism and nutrient fluxes in a shallow marine sediment previously overgrown with macroalgal mats. Estuar Coast Shelf Sci 45:613-628

Hargrave BT (1976) The central role of invertebrate faeces in sediment decomposition. In: Anderson JM, Macfadyen A (eds) The role of terrestrial and aquatic organisms in decomposition processes. Blackwell, Oxford, p 301-321

Heilskov AC, Holmer M (2001) Effects of benthic fauna on organic matter mineralization in fish-farm sediments: importance of size and abundance. ICES J Mar Sci 58: $427-434$
Holmer M, Gribsholt B, Kristensen E (2002) Effects of sea level rise on growth of Spartina anglica and oxygen dynamics in rhizosphere of salt marsh sediments. Mar Ecol Prog Ser 225:197-204

Horng CY, Taghon GL (2001) Loss rates of polycyclic aromatic hydrocarbons from sediment and deposit-feeder fecal pellets. Environ Toxicol Chem 20:1465-1473

Hulthe G, Hulth S, Hall POJ (1998) Effect of oxygen on degradation rate of refractory and labile organic matter in continental margin sediments. Geochim Cosmochim Acta 62: $1319-1328$

Jørgensen BB, Revsbech NP (1985) Diffusive boundary layers and the oxygen uptake of sediments and detritus. Limnol Oceanogr 30:111-122

Josefsen AB, Forbes TL, Rosenberg R (2002) Fate of phytodetritus in marine sediments: functional importance of macrofaunal community. Mar Ecol Prog Ser 230:71-85

Kristensen E (1993) Seasonal variations in benthic community metabolism and nitrogen dynamics in a shallow, organic poor Danish lagoon. Estuar Coast Shelf Sci 36:565-586

Kristensen E (2000) Diagenesis at the oxic/anoxic interface in marine sediments, with emphasis on the role of burrowing animals. Hydrobiologia 426:1-24

Kristensen E (2001) Impact of polychaetes (Nereis spp. and Arenicola marina) on carbon biogeochemistry in coastal marine sediment: a review. Geochem Trans 2:92-104

Kristensen E, Holmer M (2001) Decomposition of plant material in marine sediment exposed to different electron acceptors $\left(\mathrm{O}_{2}, \mathrm{NO}_{3}{ }^{-}\right.$and $\left.\mathrm{SO}_{4}{ }^{2-}\right)$, with emphasis on substrate origin, degradation stage and the role of bioturbation. Geochim Cosmochim Acta 65:419-434

Kristensen E, Pilgaard R (2001) The role of fecal pellet deposition by leaf-eating sesarmid crabs on mineralization processes in a mangrove sediment (Phuket, Thailand). In: Aller JY, Woodin SA, Aller RC (eds) Organism-sediment interactions. University of South Carolina Press, Columbia, p 369-384

Kristensen E, Andersen FØ, Blackburn TH (1992) Effects of benthic macrofauna and temperature on degradation of macroalgal detritus: the fate of organic carbon. Limnol Oceanogr 37:1404-1419

Kristiansen KD, Kristensen E, Jensen MH (2002) The influence of water column hypoxia on the behaviour of manganese and iron in sandy coastal marine sediment. Estuar Coast Shelf Sci 55:645-654

Lopez GR, Levinton JS (1987) Ecology of deposit-feeding animals in marine sediments. Q Rev Biol 62:235-260

Madigan MT, Parker J, Martinko JM (2002) Brock biology of microorganisms, 10th edn. Prentice-Hall, Englewood Cliffs, NJ

Mayer LM, Schick LL, Self RFL, Jumars PA, Findlay RH, Chen Z, Sampson S (1997) Digestive environments of benthic macroinvertebrate guts: enzymes, surfactants and dissolved organic matter. J Mar Res 55:785-812

Meyer RL, Kjaer T, Revsbech NP (2001) Use of $\mathrm{NO}_{\mathrm{x}}{ }^{-}$microsensors to estimate the activity of sediment nitrification and $\mathrm{NO}_{\mathrm{x}}{ }^{-}$consumption along an estuarine salinity, nitrate, and light gradient. Aquat Microb Ecol 26:181-193

Nedergaard RI, Risgaard-Petersen N, Finster K (2002) The importance of sulfate reduction associated with Ulva lactuca thalli during decomposition: a mesocosm experiment. J Exp Mar Biol Ecol 275:15-29

Nielsen AM, Eriksen NT, Iversen JJL, Riisgård HU (1995) Feeding, growth and respiration in the polychaetes Nereis diversicolor (facultative filter-feeder) and N. virens (omnivorous) - a comparative study. Mar Ecol Prog Ser 125: $149-158$ 
Roden EE, Tuttle JH (1996) Carbon cycling in mesohaline Chesapeake Bay sediments. 2. Kinetics of particulate and dissolved organic carbon turnover. J Mar Res 54:343-383

Rusch A, Forster S, Huettel M (2001) Bacteria, diatoms and detritus in an intertidal sandflat subject to advective transport across the water-sediment interface. Biogeochemistry $55: 1-27$

Stoeck T, Kröncke I (2001) Influence of particle mixing on vertical profiles of chlorophyll $a$ and bacterial biomass in sediments of the German Bight, Oyster Ground and Dogger Bank (North Sea). Estuar Coast Shelf Sci 52:783-795

Tenore KR, Cammen L, Findlay SEG, Phillips N (1982) Perspectives of research on detritus: do factors controlling the availability of detritus to macroconsumers depend on its source? J Mar Res 40:473-490

Tenore KR, Hanson RB, McClain J, Maccubbin AE, Hodson

Editorial responsibility: Otto Kinne (Editor),

Oldendorf/Luhe, Germany
RE (1984) Changes in composition and nutritional value to a benthic deposit feeder of decomposing detritus pools. Bull Mar Sci 35:299-311

Thomas CJ, Blair NE (2002) Transport and digestive alteration of uniformly C-13-labeled diatoms in mudflat sediments. J Mar Res 60:517-535

Van Duyl FC, Kop AJ, Kok A, Sandee JJ (1992) The impact of organic matter and macrozoobenthos on bacterial and oxygen variables in marine sediment boxcosms. Neth J Sea Res 29:343-355

Vedel A, Riisgård HU (1993) Filter-feeding in the polychaete Nereis diversicolor: growth and bioenergetics. Mar Ecol Prog Ser 100:145-152

Westrich JT, Berner RA (1984) The role of sedimentary organic matter in bacterial sulfate reduction: the G model tested. Limnol Oceanogr 29:236-249

Submitted: May 12, 2003; Accepted: October 5, 2003

Proofs received from author(s): December 15, 2003 